\title{
Dependence of GABAergic Synaptic Areas on the Interneuron Type and Target Size
}

\author{
Yoshiyuki Kubota ${ }^{1}$ and Yasuo Kawaguchi ${ }^{1,2}$ \\ ${ }^{1}$ Laboratory for Neural Circuits, Bio-Mimetic Control Research Center, The Institute of Physical and Chemical Research \\ (RIKEN), Moriyama, Nagoya 463-0003, Japan, and 2Laboratory of Cerebral Circuitry, National Institute for Physiological \\ Sciences, Myodaiji, Okazaki 444-8585, Japan
}

In the neostriatum, several types of interneuron with distinct firing patterns and expression of neuroactive substances are known to exist. We found two types of neostriatal interneurons, parvalbumin-containing fast-spiking (FS) cells and somatostatincontaining low-threshold spike (LTS) cells to both be immunoreactive for GABA at their axon terminals in immersion-fixed brain slices from rat. To reveal the differences in synaptic connections between these two types of GABAergic interneurons, the postsynaptic target and their synaptic structure were compared by three-dimensional reconstructions from electron microscopic images of intracellularly stained axon terminals. FS cells made a greater proportion of synaptic contacts onto somata than LTS cells. Although terminal boutons of FS and LTS cells were similar in volume, their synaptic junctional areas differed in size distribution and relation to the dimensions of postsynaptic dendritic shafts or spines. Whereas the synaptic junctional areas of FS cells $\left(0.024-0.435 \mu \mathrm{m}^{2} ; n=28\right)$ sharply and linearly increased with the circumference of the postsynaptic dendrites or spines $(0.939-5.146 \mu \mathrm{m})$, the slope for the junctional area of LTS cells $\left(0.02-0.103 \mu \mathrm{m}^{2} ; n=29\right)$ against circumference $(0.844-4.252 \mu \mathrm{m})$ was less steep, and a much weaker correlation was seen. In addition to the differences in firing patterns, expressed molecules, axonal arborizations, and postsynaptic targets, this variation in dependency of the synaptic area on the target size suggests functional differentiation of GABAergic interneurons.

Key words: neostriatum; interneuron; GABA; parvalbumin; somatostatin; fast spiking cell; low threshold spike; postsynaptic structure; synaptic junctional area
GABAergic interneurons are involved in the formation of response characteristics and rhythmic firing by regulating neuronal excitability (Sillito, 1992; Jefferys et al., 1996). GABAergic synaptic inputs distribute on several domains along the neuronal surface, including somata, dendrites, and axons. GABAergic interneurons are known to be heterogeneous in morphology, physiology, and chemical composition (Freund and Buzsáki, 1996; Kawaguchi and Kubota, 1997, 1998; Thomson and Deuchars, 1997; Somogyi et al., 1998). Neuronal surface domains such as somata and dendrites are innervated by multiple types of GABAergic interneuron, but the functional role of each remains to be clarified.

In the neostriatum, several types of interneurons with distinct firing patterns and expression of neuroactive substances are known to exist (Bolam and Bennet, 1995; Kawaguchi et al., 1995; Kawaguchi, 1997). Among these subtypes, parvalbumincontaining fast-spiking (FS) cells exhibiting short-duration action

\footnotetext{
Received March 8, 1999; revised Oct. 11, 1999; accepted Oct. 11, 1999.

This work was supported by Grants-in-Aid for Scientific Research from the Japanese Ministry of Education, Science, Sports and Culture, and the Frontier Research Program RIKEN. We thank Dr. R. Kado for discussions, Drs. C. J. Wilson, B. Bennett, and T. K. Hensch for comments, Dr. E. L. White for suggestions on the three-dimensional reconstruction analysis program, Dr. A. M. Thomson for advice on the histological procedure, and Ms. N. Wada and S. Kato for technical assistance. We are grateful to Dr. R. Benoit for the gift of antiserum against somatostatin.

Correspondence should be addressed to Yasuo Kawaguchi, Laboratory of Cerebral Circuitry, National Institute for Physiological Sciences, Myodaiji, Okazaki 444-8585, Japan. E-mail: yasuo@nips.ac.jp.

Copyright (C) 1999 Society for Neuroscience $0270-6474 / 00 / 200375-12 \$ 15.00 / 0$
}

potentials at constant spike frequency are considered to be GABAergic because they induce $\mathrm{GABA}_{\mathrm{A}}$ receptor-mediated inhibition (Koós and Tepper, 1999), and parvalbumin cells express GABA and glutamic acid decarboxylase (GAD; an enzyme involved in GABA synthesis) (Cowan et al., 1990; Kita et al., 1990; Kawaguchi, 1993; Kubota et al., 1993, Bennett and Bolam, 1994; Augood et al., 1995). In addition, somatostatin-containing cells exhibiting low-threshold spikes from hyperpolarized potentials, followed by persistent depolarizations, [low-threshold spike (LTS) cells] may also be GABAergic because somatostatin cells were found to be immunoreactive for $67 \mathrm{kDa}$ GAD (GAD67) when rats are injected with colchicine into the lateral ventricles or neostriatum (Vuillet et al., 1990; Kubota et al., 1993). However, GAD mRNAs are not normally detected in somatostatin cells (Chesselet and Robbins, 1989; Catania et al., 1995), and only a few somata positive for somatostatin show GABA immunoreactivity (Aoki and Pickel, 1989; Kubota et al., 1993).

In this study, we found the axon terminals of physiologically identified LTS cells as well as FS cells to be immunoreactive for GABA. To reveal the synaptic differences of these two types of GABAergic interneurons, postsynaptic targets were compared, using three-dimensional (3-D) reconstruction of electron microscopic images. Because the postsynaptic junctional area may be related to the size of the synaptic current (Nusser et al., 1997, 1998; Mackenzie et al., 1999), its dimensions were measured from the reconstructions, along with the size of the presynaptic boutons and the postsynaptic targets. The results indicate that the two types of GABAergic interneurons with distinct firing patterns and neuroactive substances have different relationships with postsynaptic elements. 


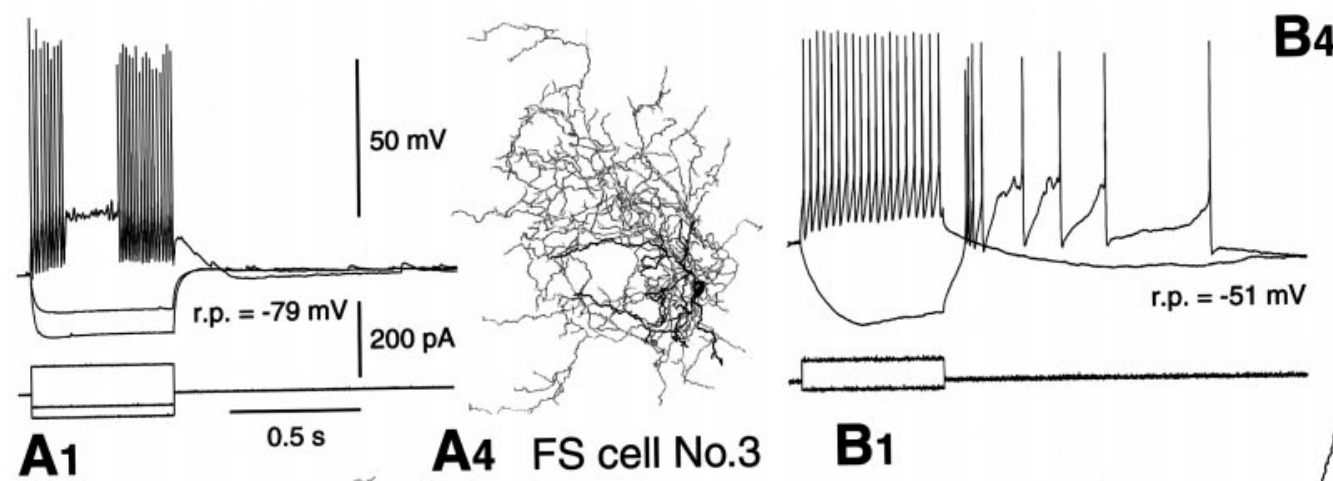

\section{B4 LTS cell No.3}
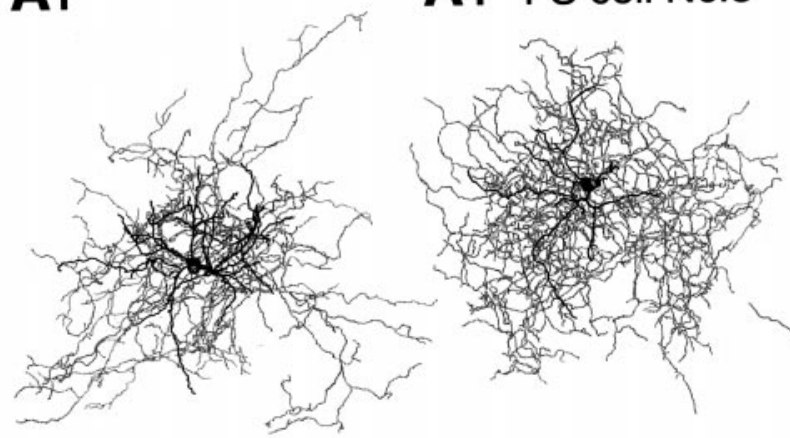

\section{A2 $\quad$ FS cell No.1 A3 FS cell No.2}
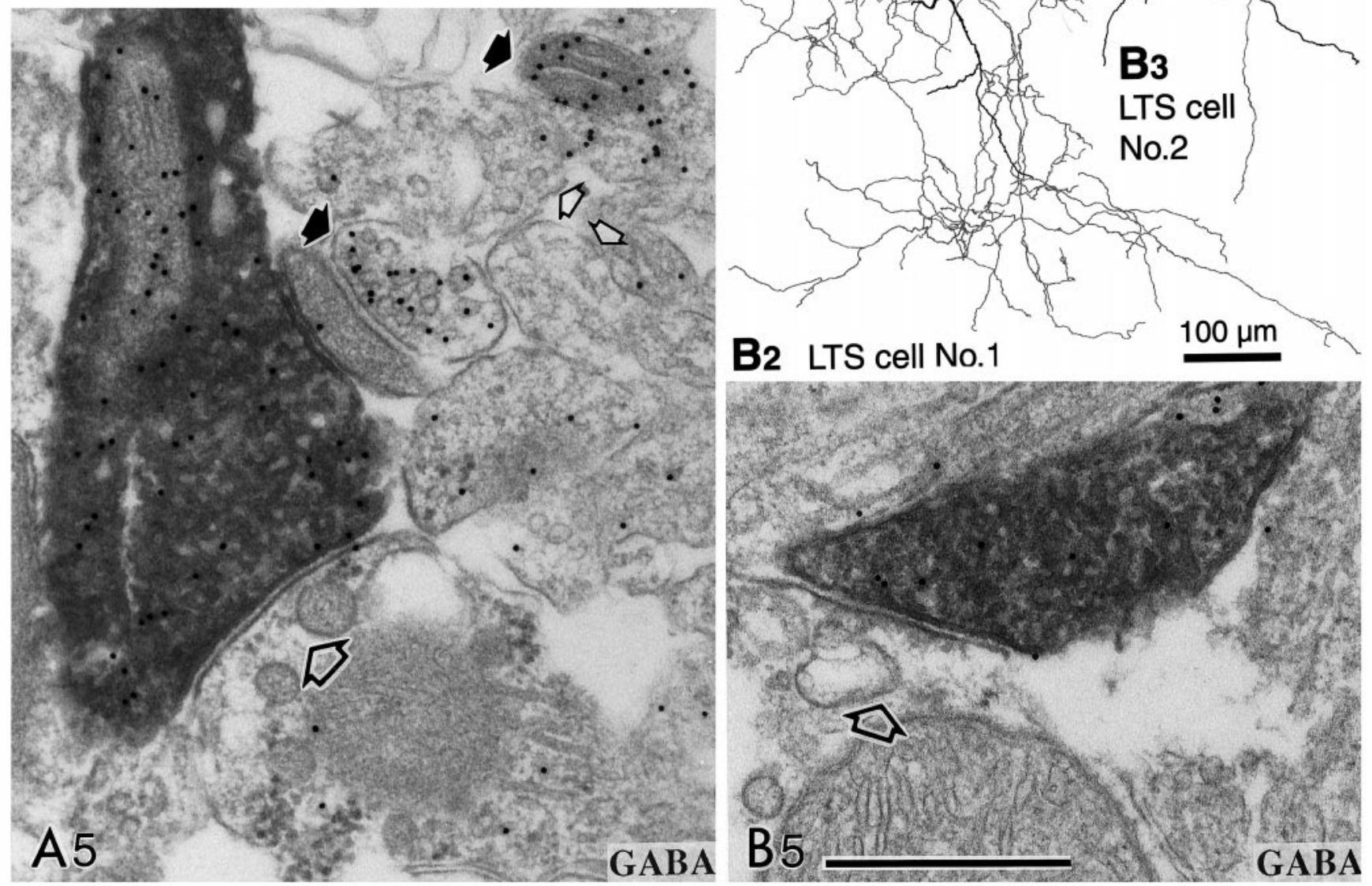

Figure 1. Physiological characterization and GABA-immunoreactive terminals of two neostriatal interneuron types. The somata and dendrites are shown in black and the axons in gray. A, FS cells. $A_{l}$, An FS cell with hyperpolarized resting potential (r.p.), which rapidly, but transiently, fired short-duration spikes with a constant interspike interval when depolarized with a current pulse. Firing sometimes resumed during the depolarization. $A_{2}-A_{4}$, Three FS cells used for electron microscopic studies. They have restricted dendritic fields and axons densely collateralizing in the dendritic field. $A_{5}$, An identified axon terminal of FS cell number 1 making a symmetrical synapse with a dendritic shaft (large open arrow). The terminal is immunoreactive for GABA as shown by the presence of $15 \mathrm{~nm}$ colloidal gold particles. Strongly ( filled arrows) and very weakly labeled neural elements (small open arrows) are apparent beside the FS cell terminal. B, LTS cells. $B_{1}$, An LTS cell with depolarized resting potentials (Figure legend continues) 

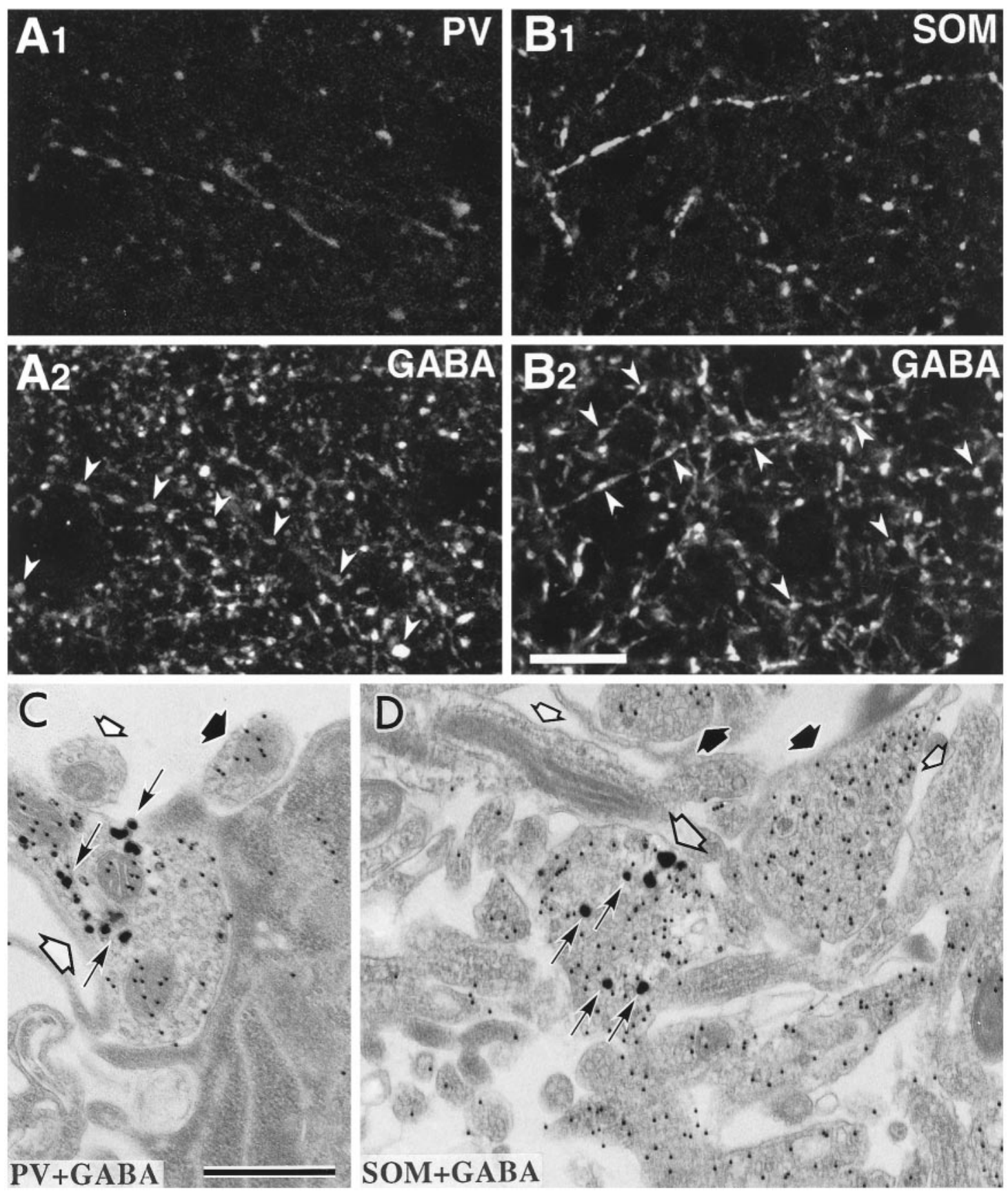

Figure 2. GABA immunoreactivity of parvalbumin- or somatostatin-containing fibers in immersion-fixed slices. $A$, Laser confocal images of the same section stained by double immunofluorescence for parvalbumin $\left(A_{1}\right)$ and GABA $\left(A_{2}\right)$. Most parvalbumin-positive fibers show GABA immunoreactivity (arrowheads). B, Laser confocal images of the same section for somatostatin $\left(B_{1}\right)$ and GABA $\left(B_{2}\right)$ immunofluorescence. Many somatostatinimmunoreactive fibers are GABA-positive (arrowheads). Scale bar, $20 \mu \mathrm{m}$. $C, D$, Double immunolabeled ultrathin sections. A parvalbuminimmunoreactive axon terminal $(C$, large open arrow) and a somatostatin-immunoreactive axon $(D$, large open arrow) labeled with intensified gold particles (arrows) are immunoreactive for GABA, as indicated by the $15 \mathrm{~nm}$ colloidal gold particles. Neural elements with many colloidal gold particles (thick filled arrows) and with very few or no particles (small open arrows) are present. Scale bar, $0.5 \mu \mathrm{m}$.

(r.p.) and high input resistances. Two potential responses are shown superposed for the injected currents shown in the bottom traces (scales as in $A_{1}$ ). Note that the cell fired a low-threshold spike after cessation of a hyperpolarization pulse. $B_{2}-B_{4}$, Three LTS cells used for electron microscopic observation. They have less compact dendritic arborization, often running long distances without branching or turning. The axons are also diffusely distributed, and the entire axonal field extends as far as $1000 \mu \mathrm{m} . B_{5}$, An identified axon terminal of LTS cell number 1 making a symmetrical synapse with a dendritic shaft (open arrow). This terminal is also immunoreactive for GABA, as shown by the 15 nm colloidal gold particles. Scale bars: $A_{2}-A_{4}$, $B_{2}-B_{4}, 100 \mu \mathrm{m} ; A_{5}, B_{5}, 0.5 \mu \mathrm{m}$. 

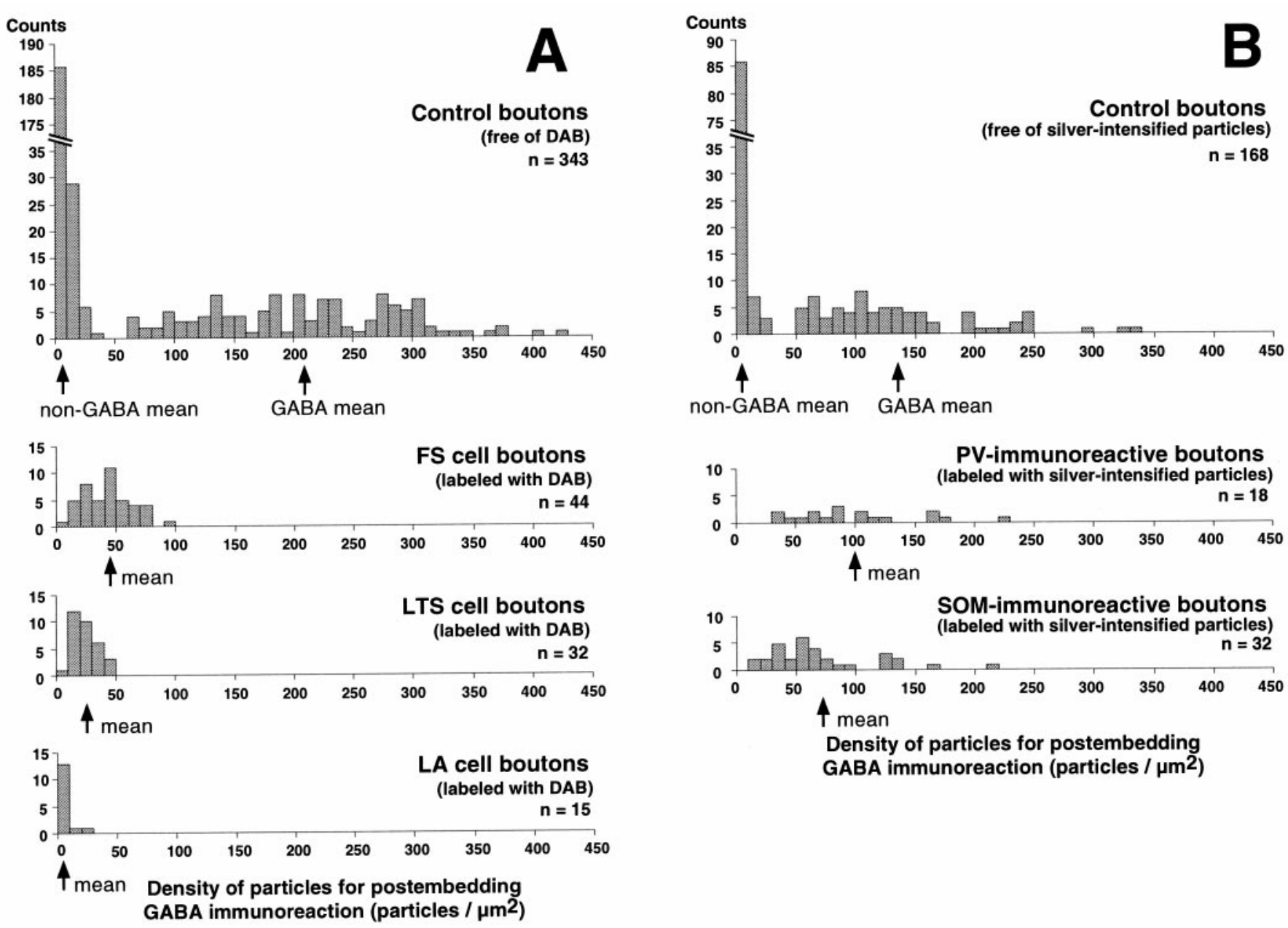

Figure 3. Densities of colloidal gold particles on postembedding GABA immunoreactions at the axonal boutons of interneuron types. $A$, The distributions of particle density for GABA at the FS, LTS, and LA cell boutons identified physiologically and stained with DAB. Control boutons not stained intracellularly and free of DAB reaction products could be divided into two groups with the densities for GABA from 0 to 34.6 particles/ $\mu \mathrm{m}^{2}$ and from 61.3 to 420.4 particles/ $\mu \mathrm{m}^{2}$. The former were assumed to be non-GABAergic and the latter to be GABAergic. $B$, The distributions of particle densities for GABA at parvalbumin $(P V)$ - and somatostatin $(S O M)$-containing boutons identified with silver-intensified gold particles at pre-embedding immunohistochemistry. Control boutons not stained by pre-embedding immunohistochemistry and free of silver-intensified gold particles could be divided into two groups with densities for GABA from 0 to 27.7 particles $/ \mu \mathrm{m}^{2}$ and from 50.4 to 335.6 particles $/ \mu \mathrm{m}^{2}$. Arrows indicate mean values for non-GABAergic (non-GABA mean) and GABAergic (GABA mean) boutons and for boutons of each cell type (mean).

\section{MATERIALS AND METHODS}

\section{Whole-cell recording and intracellular staining}

The experiments were performed on young Wistar rats (18-22 d postnatal). Animals were deeply anesthetized with ether and decapitated. The brains were quickly removed and submerged in ice-cold physiological Ringer's solution. Two hundred-micrometer-thick sections of neostriatum were cut and immersed in a buffered solution (in $\mathrm{mm}: \mathrm{NaCl}$, 124.0; KCl, 3.0; $\mathrm{CaCl}_{2}, 2.4 ; \mathrm{MgCl}_{2}, 1.2 ; \mathrm{NaHCO}_{3}, 26.0 ; \mathrm{NaH}_{2} \mathrm{PO}_{4}, 1.0$; and glucose, 10.0) aerated with a mixture of $95 \% \mathrm{O}_{2}$ and $5 \% \mathrm{CO}_{2}$.

Neostriatal cells were recorded in a whole-cell mode at $32^{\circ} \mathrm{C}$ using a $40 \times$ water-immersion objective. The electrode solution for the currentclamp recording consisted of (in $\mathrm{mM}$ ): potassium methylsulfate $115, \mathrm{KCl}$ 5.0, EGTA 0.5, $\mathrm{MgCl}_{2}$ 1.7, ATP 4.0, GTP 0.3, HEPES 8.5, and biocytin 17. Current-clamp recordings were made in the bridge mode using capacitance neutralization with an Axoclamp-2B amplifier (Axon Instruments, Foster City, CA). Input resistances of cells were determined by passing hyperpolarizing current pulses (duration, 500-600 msec) and inducing voltage shifts of $6-15 \mathrm{mV}$ negative to rest. Spike widths at half amplitude were measured for spikes elicited by depolarizing current pulses (duration, $50 \mathrm{msec}$ ) of threshold strength. Generation of lowthreshold spikes was investigated by depolarizing current pulses of threshold strength from -75 to $-85 \mathrm{mV}$.

Tissue slices containing biocytin-loaded cells were fixed by immersion in $4 \%$ paraformaldehyde, $2.5 \%$ glutaraldehyde, and $0.2 \%$ picric acid overnight at $4^{\circ} \mathrm{C}$, and incubated in $0.1 \mathrm{M}$ sodium phosphate buffer $(\mathrm{PB})$ containing $10 \%$ sucrose for $1 \mathrm{hr}$ and $20 \%$ sucrose for $3 \mathrm{hr}$, followed by a freeze-thawing procedure using liquid nitrogen twice. The slices were then incubated in PB containing 1\% sodium borohydrate for $30 \mathrm{~min}$ and in $0.05 \mathrm{M}$ Tris-HCl-buffered saline (TBS) containing $1 \% \mathrm{H}_{2} \mathrm{O}_{2}$ for 30 min before incubation with avidin-biotin-peroxidase complex in TBS containing $0.05 \%$ Triton X-100 (TX) overnight at $4^{\circ} \mathrm{C}$. After washing in TBS, the slices were reacted with 3,3'-diaminobenzidine tetrahydrochloride (DAB) $(0.05 \%)$ and $\mathrm{H}_{2} \mathrm{O}_{2}(0.003 \%)$ in Tris- $\mathrm{HCl}$ buffer. They were then post-fixed for $20 \mathrm{~min}$ in $0.5 \% \mathrm{OsO}_{4}$ in $\mathrm{PB}$, dehydrated in graded ethanol with $1 \%$ uranyl acetate at the $70 \%$ ethanol dehydration state, and flat-embedded on silicon-coated glass slides in Epon. After reconstruction with a camera lucida, stained cells were serially sectioned using an ultramicrotome.

\section{Postembedding immunohistochemistry for $G A B A$}

Ultrathin sections on nickel mesh grids (200 mesh) were washed with TBS containing $0.1 \%$ TX and incubated with antiserum for GABA (Sigma, St. Louis, MO; 1:5000) in TBS containing $0.1 \%$ TX overnight at $20^{\circ} \mathrm{C}$, followed by incubation with colloidal gold $(15 \mathrm{~nm})$-conjugated anti-rabbit $\mathrm{IgG}$ (BioCell; $1: 100$ ) overnight at $33^{\circ} \mathrm{C}$ in TBS containing 0.1\% TX (Phend et al., 1992; Buhl et al., 1994) and staining with 1\% 

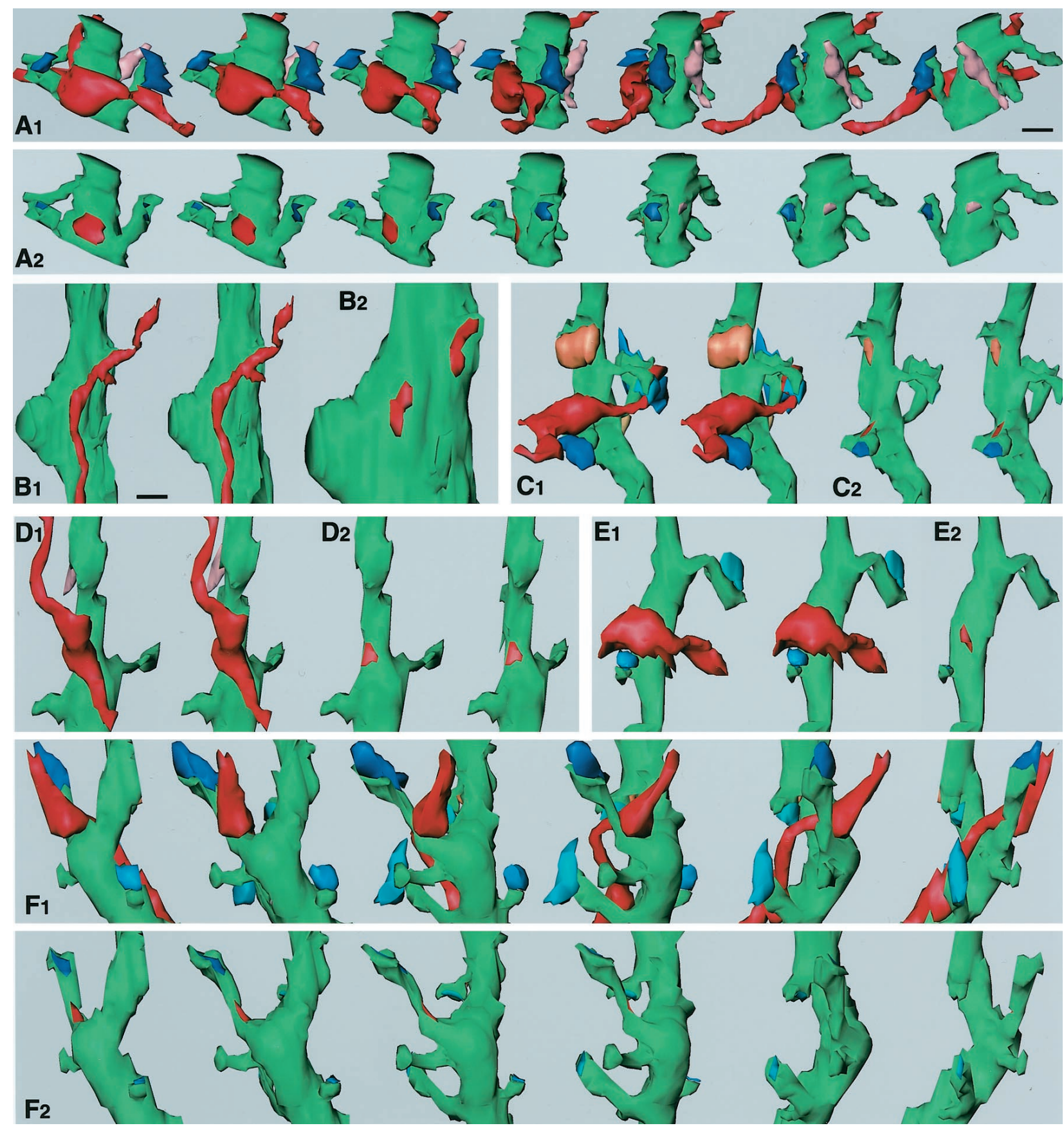

Figure 4. Three-dimensional analysis of terminals of FS $(A-C)$ and LTS $(D-F)$ cells. In $\mathrm{B}_{1}, C_{1}, C_{2}, D_{1}, D_{2}$, and $E_{1}$, two images are shown for stereoscopic observation. $A_{l}, 3$-D reconstruction images of a terminal of FS cell number 1 and associated structures are rotated $\sim 25^{\circ}$ each from left to right. An intracellularly labeled axon terminal of the FS cell (red) makes a symmetrical synapse on a postsynaptic spiny dendrite (green). Two of the spine heads receive asymmetrical synapses (blue and dark blue). The other terminal (pink) makes a symmetrical contact on the other side of the dendrite. $A_{2}$, The same dendrite as in $A_{1}$ is rotated in the same way except that synaptic junctions are indicated by the same colors as the terminal boutons in $A_{1}$. The synaptic junctional area of the FS cell terminal (red) was $0.298 \mu \mathrm{m}^{2} . B_{1}$, Two successive axonal boutons of FS cell number 1 make synaptic junctions $0.8 \mu \mathrm{m}$ apart on the same proximal dendrite $2 \mu \mathrm{m}$ distant from the soma. Two synaptic junctions are shown in $B_{2}$ at the same magnification as in $A$. The synaptic junctional areas of the FS cell terminals were 0.19 (left) and $0.18 \mu \mathrm{m}^{2}$ (right), respectively. $C_{l}$, Another axon terminal (red) of FS cell number 1 makes a symmetrical synaptic contact on a spine neck. The spine receives an asymmetrical terminal on the head (dark blue) and another spine also an asymmetrical terminal (blue). Another terminal (orange) makes a symmetrical synapse on the dendritic shaft. $C_{2}$, The same dendrite as in $C_{1}$ except that synaptic junctions are indicated by the same colors as the terminal boutons in $C_{l}$. The synaptic junctional area of the FS cell terminal (red) was 0.04 $\mu \mathrm{m}^{2} . D_{l}$, A terminal of LTS cell number 1 (red) makes a symmetrical synaptic contact on a shaft of a spiny dendrite $($ green $)$. $D_{2}$, The synaptic junctional area $\left(0.088 \mu \mathrm{m}^{2}\right)$ is indicated by red. $E_{l}$, A terminal of LTS cell number 2 (red) makes a symmetrical synaptic junction on a trunk of a spiny dendrite ( green). Two spines nearby receive asymmetrical synaptic terminals on the head (blue). $E_{2}$, The synaptic junctional area $\left(0.068 \mu \mathrm{m}^{2}\right)$ is indicated by red. $F_{l}$, A terminal of LTS cell number 1 and associated structures are rotated $\sim 30^{\circ}$ from left to right. The terminal (red) makes a symmetrical synaptic contact on a spine stalk. The spine head receives an asymmetrical terminal (dark blue) and other three spines, also asymmetrical terminals (blue), on the head. $F_{2}$, The same dendrite as in $F_{1}$ is rotated in the same way, except that synaptic junctions are indicated by the same colors as the terminal boutons in $F_{1}$. The synaptic junctional area of the terminal (red) was $0.068 \mu \mathrm{m}^{2}$. Scale bars: $A, B_{2}, C-F, 0.5 \mu \mathrm{m} ; B_{1}, 0.8 \mu \mathrm{m}$. 
Table 1. Postsynaptic targets of two types of neostriatal interneurons

\begin{tabular}{lcccc} 
& & & \multicolumn{2}{c}{ Dendrite } \\
\cline { 4 - 4 } Cell type & Total & Soma & Shaft & Spine \\
\hline FS & & & & \\
1 & 15 & 1 & $13(10)$ & 1 \\
2 & 12 & 7 & $5(2)$ & 0 \\
3 & 12 & 3 & $8(3)$ & 1 \\
Total & 39 & 11 & $26(15)$ & 2 \\
LTS & 10 & 1 & $8(4)$ & 1 \\
1 & 12 & 0 & $11(4)$ & 1 \\
2 & 8 & 0 & $8(2)$ & 0 \\
3 & 30 & 1 & $27(10)$ & 2 \\
Total & & & & \\
\hline
\end{tabular}

Numbers of targets identified as spiny dendrites are in parentheses.

uranyl acetate and lead citrate. No immunoreaction was observed in ultrathin sections incubated in antiserum for GABA that had been preabsorbed with an excess of bovine serum albumin (BSA)-GABA complex $(0.1 \mathrm{~mm})$. Electron micrographs were taken at $100 \mathrm{kV}$ with a Hitachi H-7000 electron microscope. Colloidal gold particles were found commonly in both the mitochondria and cytosol of GABA-positive terminals. Although they were fewer with than without intracellular DAB staining, probably because of prevention of the antigen-antibody interaction by DAB products, the densities of colloidal gold particles clearly differed between GABA-positive and -negative axons or dendrites, irrespective of DAB reaction products, as described earlier for cortical slice preparations (Kawaguchi and Kubota, 1998). In the DABstained GABA-positive terminals, there were more particles on mitochondria without reaction products than in the cytosol filled with DAB reaction products.

\section{Three-dimensional reconstruction of successive ultrathin sections}

Serial ultrathin (90 $\mathrm{nm}$ thickness) sections were mounted on formvarcoated single-slot $(2 \times 1 \mathrm{~mm})$ grids. Electron microscopic images of the labeled terminals and associated structures were captured using a CCD camera (Kodak Megaplus 1.4i) and reconstructed using a 3-D reconstruction system with the software developed by Noesis (Vélizy, France) as an extension of their Visilog program.

\section{Double-labeling immunohistochemistry}

Two hundred-micrometer-thick slices of rat neostriatum (18-40 d postnatal) were incubated for $2-3 \mathrm{hr}$ in the above-described oxygenated extracellular solution. After further incubation for $3 \mathrm{~min}$ in an oxygenated $\mathrm{Ca}^{2+}$-free solution containing (in $\mathrm{mM}$ ) 250.0 sucrose, $3.0 \mathrm{KCl}, 5.0$ $\mathrm{MgCl}_{2}, 26.0 \mathrm{NaHCO}_{3}$, and 10.0 glucose to prevent transmitter release from axon terminals, the slices were immersed in one of the fixatives $(4 \%$ paraformaldehyde, $2.5 \%$ glutaraldehyde, and $0.2 \%$ picric acid for fluorescence and $4 \%$ paraformaldehyde, $0.5 \%$ glutaraldehyde, and $0.2 \%$ picric acid for EM) and irradiated for $20 \mathrm{sec}$ in a microwave oven. Then they were immersed in the same fixative overnight at $4{ }^{\circ} \mathrm{C}$ and incubated in PB containing $10 \%$ sucrose for $1 \mathrm{hr}$ and $20 \%$ sucrose for $2-3 \mathrm{hr}$. Double immunofluorescence. The slices were cut in a cryostat at $6 \mu \mathrm{m}$ thickness. Sections were washed in TBS and incubated with a mixture of (1) a rabbit antiserum against parvalbumin (Swant, Bellinzona, Switzerland; diluted 1:2000) and a mouse monoclonal antibody against GABA (Chemicon, Temecula, CA; 1:200), (2) a rabbit antiserum against somatostatin 28 (1-12) (S-320; a gift from Dr. Robert Benoit, Montreal General Hospital; 1:4000) and the GABA antibody, or (3) a rabbit antiserum against dopamine (Incstar, Stillwater, MN; 1:4000) and the GABA antibody in TBS containing 10\% normal goat serum (NGS), $2 \%$ BSA, and $0.5 \%$ TX overnight. After washing, the sections were incubated with a combination of Texas red-conjugated anti-rabbit IgG (N2034; 1:100; Amersham, Arlington Heights, IL) and dichlorotriaginyl amino fluorescein (DTAF)-conjugated anti-mouse IgG (192F; 1:100; Chemicon) in TBS containing NGS, BSA, and TX for $3 \mathrm{hr}$ or overnight. The sections were coverslipped in FluoroGuard (Bio-Rad, Hercules, CA) and observed under a laser confocal microscope (MRC-1024; Bio-Rad).

Double immunolabeling at the EM level. After freeze-thawing in liquid nitrogen, neostriatal slices were embedded in a $12 \%$ gelatin solution, fixed, and re-sectioned on a slicer (VT 1000S; Leica, Nussloch, Germany) at $50 \mu \mathrm{m}$ thickness (Deuchars et al., 1994). Sections were washed in TBS and incubated with the rabbit antiserum against parvalbumin or somatostatin 28 (1-12) in TBS containing $10 \%$ NGS, $2 \%$ BSA and $0.04 \%$ TX overnight. After washes with TBS, the sections were incubated with a 1 $\mathrm{nm}$ colloidal gold-labeled goat anti-rabbit IgG (RPN470; 1:50; Amersham) in TBS containing $0.8 \%$ BSA, $0.02 \%$ gelatin, and $2 \mathrm{mM} \mathrm{NaN}_{3}$ overnight. After silver amplification (silver enhancement kit RPN491; Amersham), the sections were prepared for electron microscopy as described above. Ultrathin sections were cut, and GABA postembedding immunohistochemistry was applied using mouse monoclonal antibody against GABA (1:100; Chemicon) and then colloidal gold (15 nm)conjugated anti-mouse IgG (BioCell).

Data given are mean \pm SD values. The Mann-Whitney $U$ test was used for statistical comparisons

\section{RESULTS GABA-immunoreactive terminals of neostriatal interneuron subtypes}

The neostriatal interneurons can be divided into several classes (Kawaguchi, 1993, 1997): (1) FS cells have low input resistances and hyperpolarized membrane potentials, fire short-duration action potentials at constant spike frequency during depolarizing pulses (Fig. $1 A_{1}$ ), and are immunoreactive for parvalbumin; (2) LTS cells induce LTS from hyperpolarized potentials, followed by persistent depolarizations (Fig. $1 B_{1}$ ) and are positive for somatostatin and nitric oxide synthase (NOS); (3) large cholinergic cells show long-lasting afterhyperpolarization after spikes (long-lasting afterhyperpolarization cells, LA cells).

To identify which interneurons are GABAergic, GABA immunoreactivity in the axon collaterals of physiologically identified, intracellularly stained interneurons was investigated by postembedding immunohistochemistry of ultrathin sections using colloidal gold particles (Kawaguchi and Kubota, 1998). The FS cells $(n=3)$ had resting potentials of $-77.3 \pm 3.8(\mathrm{SD}) \mathrm{mV}$, input resistances of $263 \pm 79 \mathrm{M} \Omega$, spike-widths at half amplitude of $0.39 \pm 0.05 \mathrm{msec}$, cross-sectional somatic areas of $109 \pm 14 \mu \mathrm{m}^{2}$, and maximal somatic diameters of $14.0 \pm 1.5 \mu \mathrm{m}$. The LTS cells $(n=3)$ had resting potentials of $-53.7 \pm 2.9 \mathrm{mV}$, input resistances of $1523 \pm 141 \mathrm{M} \Omega$, spike-widths at half amplitude of $1.1 \pm$ $0.4 \mathrm{msec}$, cross-sectional somatic areas of $123 \pm 20 \mu \mathrm{m}^{2}$, and maximal somatic diameters of $18.1 \pm 2.3 \mu \mathrm{m}$. The LA cells $(n=$ 2) had resting potentials of $-57.5 \pm 4.9 \mathrm{mV}$, input resistances of $517 \pm 156 \mathrm{M} \Omega$, spike-widths at half amplitude of $0.93 \pm 0.04$ msec, cross-sectional somatic areas of $352 \pm 18 \mu \mathrm{m}^{2}$, and maximal somatic diameters of $29.9 \pm 3.1 \mu \mathrm{m}$. The amount of current necessary to elicit a spike was greater in FS cells than in LTS cells. FS cells abruptly started nonadapting repetitive discharges above threshold intensity in response to depolarizing current pulses, ceased firing abruptly, and sometimes resumed again after a quiescent period within the period of the same depolarizing pulse (Fig. $1 A_{1}$ ). On the other hand, LTS cells showed low-threshold spikes elicited from hyperpolarized potentials $\left(\right.$ Fig. $\left.1 B_{1}\right)$. FS cells densely innervated areas close to the dendritic field (Fig. $1 A_{2}-$ $A_{4}$ ), whereas LTS cells innervated wider areas (Fig. $1 B_{2}-B_{4}$ ).

GABA immunoreactivity was investigated at the axonal boutons of the FS, LTS, and LA cells. All terminals of three FS cells showed gold particle labeling for GABA (Fig. $1 A_{5}$ ). This was also the case for most axonal boutons of three LTS cells (Fig. $1 B_{5}$ ), but the density of colloidal gold particles on terminals was only approximately half that of FS cells. Very few or no gold particles were found on axonal boutons and fibers of two LA cells (data not shown). The densities of colloidal gold particles for GABA on the boutons were $43.5 \pm 20.1 \mathrm{particles} / \mu \mathrm{m}^{2}$ (range, $7.0-95.4 ; n=$ 

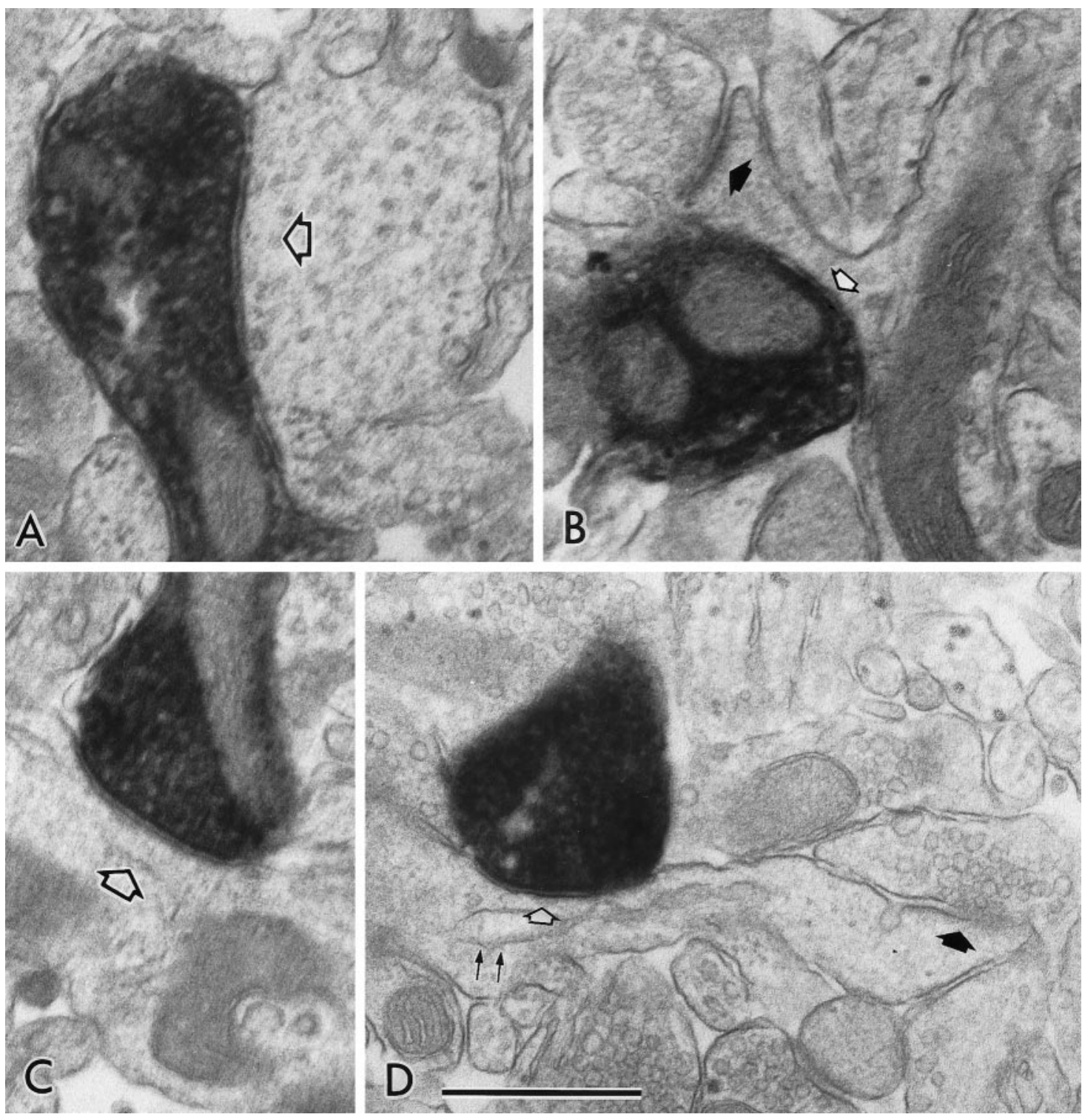

Figure 5. Electron micrographs showing symmetrical synapses of axon terminals used for 3-D reconstructions. $A, B$, The symmetrical synapses in Figure 4, $A$ and $C$ (FS cell number 1), on the dendritic shaft (open arrow) and on the spine neck (open arrow), respectively. $B$, Filled arrow, An asymmetrical synapse on the spine head. $C, D$, The symmetrical synapses in Figure $4, D$ and $F$ (LTS cell number 1), on the dendritic shaft (open arrow) and on the spine neck (open arrow), respectively. D, Filled arrow, An asymmetrical synapse on the spine head. D, Double arrows, A spine apparatus. Scale bar, $0.5 \mu \mathrm{m}$.

44) for an FS cell (FS cell number 1) (see Fig. 3A) and $24.5 \pm 10.4$ particles $/ \mu \mathrm{m}^{2}$ (range, $8.2-48.8 ; n=32$ ) for an LTS cell (LTS cell number 1) (see Fig. $3 A$ ), the difference being significant $(p<$ $0.0001)$. Other DAB-free boutons near the biocytin-loaded DABstained ones could be divided into two groups on the basis of the particle for GABA density: one with the range from 0 to 34.6 particles $/ \mu \mathrm{m}^{2}(5.0 \pm 5.9 ; n=222)$ and the other from 61.3 to 420.4 particles $/ \mu \mathrm{m}^{2}(209.2 \pm 82.2 ; n=121)$ (see Fig. $\left.3 A\right)$. We assumed the former to be non-GABAergic and the latter to be GABAergic. Particles on the biocytin-loaded DAB-stained boutons of the FS and LTS cells were significantly more numerous than those on non-GABAergic ones, but significantly fewer than those on GABAergic ones $(p<0.0001)$. These observations indicated the axonal boutons of FS and LTS cells to be positive for GABA. However, dense DAB reaction products may prevent the antigen-antibody interaction in postembedding immunohistochemistry (Kawaguchi and Kubota, 1998). Very few or no gold particles $\left(4.5 \pm 4.3\right.$ particles $/ \mu \mathrm{m}^{2}$; range, $\left.0-24.5 ; n=15\right)$ were found on the axonal boutons and fibers of an LA cell (see Fig. $3 A$ ), similar to the non-GABA case.

To confirm the existence of multiple types of GABAergic interneurons in the neostriatum, the coexistence of GABA with parvalbumin or somatostatin was investigated using immersionfixed slices. Double immunofluorescence revealed most of the parvalbumin-positive varicose fibers and more than half of the somatostatin-positive varicose fibers to show GABA immunoreactivity (Fig. $2 A, B$ ). In contrast, dopamine-positive fibers were negative (data not shown).

At the electron microscopic level, parvalbumin- and somatostatin-immunoreactive axon terminals labeled with silverintensified gold particles demonstrated colloidal gold particles from the GABA immunoreaction (Fig. $2 C, D$ ). The particle density for GABA on parvalbumin-immunoreactive axonal boutons (100.5 \pm 52.3 particles/ $\mu \mathrm{m}^{2}$; range, 32.3-227.1; $\left.n=18\right)$ was 
Table 2. Sizes of synaptic structures of FS and LTS cells

\begin{tabular}{|c|c|c|c|c|c|c|c|}
\hline \multirow[b]{2}{*}{ Cell type } & \multirow{2}{*}{$\begin{array}{l}\text { Postsynaptic } \\
\text { target }\end{array}$} & \multicolumn{2}{|l|}{ Bouton volume } & \multicolumn{2}{|c|}{ Synaptic junction area } & \multicolumn{2}{|c|}{$\begin{array}{l}\text { Postsynaptic dendritic shaft/ } \\
\text { spine circumference }\end{array}$} \\
\hline & & Mean $\pm \operatorname{SD}\left(\mu \mathrm{m}^{3}\right)$ & $n$ & Mean $\pm \operatorname{SD}\left(\mu \mathrm{m}^{2}\right)$ & $n$ & Mean $\pm \mathrm{SD}(\mu \mathrm{m})$ & $n$ \\
\hline \multirow[t]{2}{*}{ FS } & Dendrite & $\begin{array}{c}0.262 \pm 0.126 \\
(0.103-0.722)\end{array}$ & 27 & $\begin{array}{l}0.151 \pm 0.106^{*} \\
(0.024-0.435)\end{array}$ & 28 & $\begin{array}{c}2.119 \pm 1.247 \\
(0.939-5.146)\end{array}$ & 28 \\
\hline & Soma & $\begin{array}{l}0.281 \pm 0.09 \\
(0.161-0.371)\end{array}$ & 11 & $\begin{array}{c}0.278 \pm 0.138^{*} \\
(0.044-0.514)\end{array}$ & 11 & & \\
\hline \multirow[t]{2}{*}{ LTS } & Dendrite & $\begin{array}{c}0.191 \pm 0.125 \\
(0.043-0.523)\end{array}$ & 27 & $\begin{array}{c}0.055 \pm 0.023^{*} \\
(0.02-0.103)\end{array}$ & 29 & $\begin{array}{l}2.087 \pm 0.879 \\
(0.844-4.252)\end{array}$ & 29 \\
\hline & Soma & 1.116 & 1 & 0.361 & 1 & & \\
\hline
\end{tabular}

Ranges are in parentheses.

* Significant differences among these three groups $(p<0.005)$.

significantly larger than that on somatostatin-immunoreactive ones $\left(72.9 \pm 46.9\right.$ particles $/ \mu \mathrm{m}^{2}$; range, $\left.15.5-216.1 ; n=33\right)(p<$ $0.05)$. Other boutons free of silver-intensified gold particles near the parvalbumin- or somatostatin-immunoreactive ones could be divided into two groups on the basis of the particle density for GABA: one with the range from 0 to 27.7 particles $/ \mu \mathrm{m}^{2}(3.3 \pm$ $5.5 ; n=72)$ and the other from 50.4 to 335.6 particles $/ \mu \mathrm{m}^{2}$ $(135.6 \pm 66.1 ; n=96)$ (Fig. 3B). The former were assumed to be non-GABAergic and the latter to be GABAergic. Particles on for GABA parvalbumin boutons were significantly more numerous than those on non-GABAergic ones $(p<0.0001)$ and were not statistically different from those on GABAergic ones $(p>0.05)$, indicating parvalbumin axons to be positive for GABA. Particles for GABA on somatostatin boutons were significantly more numerous than on GABA-negative $(p<0.0001)$, but significantly fewer than on GABA-positive ones $(p<0.0001)$. These results indicate that somatostatin boutons express GABA with lower content than their parvalbumin counterparts.

\section{Postsynaptic targets and synaptic structures of axon terminals of FS and LTS cells}

To assess the differences in synaptic connections between these two GABAergic interneuron types, postsynaptic targets and synaptic structures made by their axon terminals were compared. For this purpose, 38 terminal boutons of three FS cells and 28 terminal boutons of three LTS cells were reconstructed three-
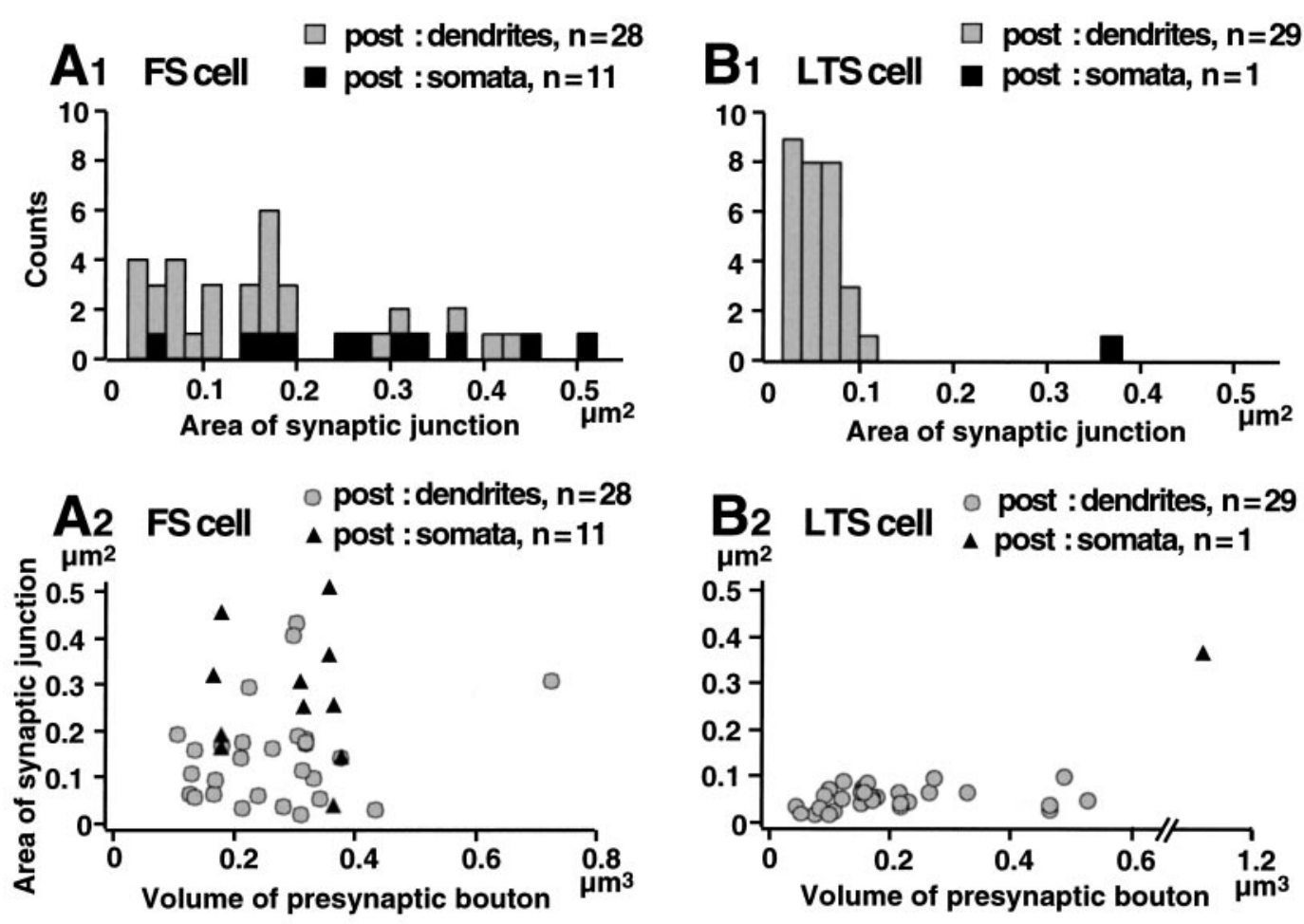

Figure 6. Synaptic junction areas and volumes for terminal boutons of FS cells $(A)$ and LTS cells $(B)$. $A_{l}, B_{l}$, Distributions of synaptic junction areas of FS and LTS cell terminals. The junctional areas of synapses onto dendrites of FS cells are more variable than for LTS cells, with values of $0.024-0.435$ $\mu \mathrm{m}^{2}$, as opposed to $<0.103 \mu \mathrm{m}^{2}$. Similar size variation was seen for the junctional areas onto somata of FS $\left(0.044-0.514 \mu \mathrm{m}^{2}\right)$, but a larger junctional area $\left(0.361 \mu \mathrm{m}^{2}\right)$ was found for a somatic synapse of the LTS cell. Synapses on somata are shown in black, and on dendrites in gray. $A_{2}, B_{2}$, Relationship between synaptic junction area and terminal bouton volume (gray circles on dendrites; black triangles on somata) for FS and LTS cells. The bouton volumes of FS and LTS cell terminals are distributed similarly. No correlation was found between bouton volume and junctional area. 

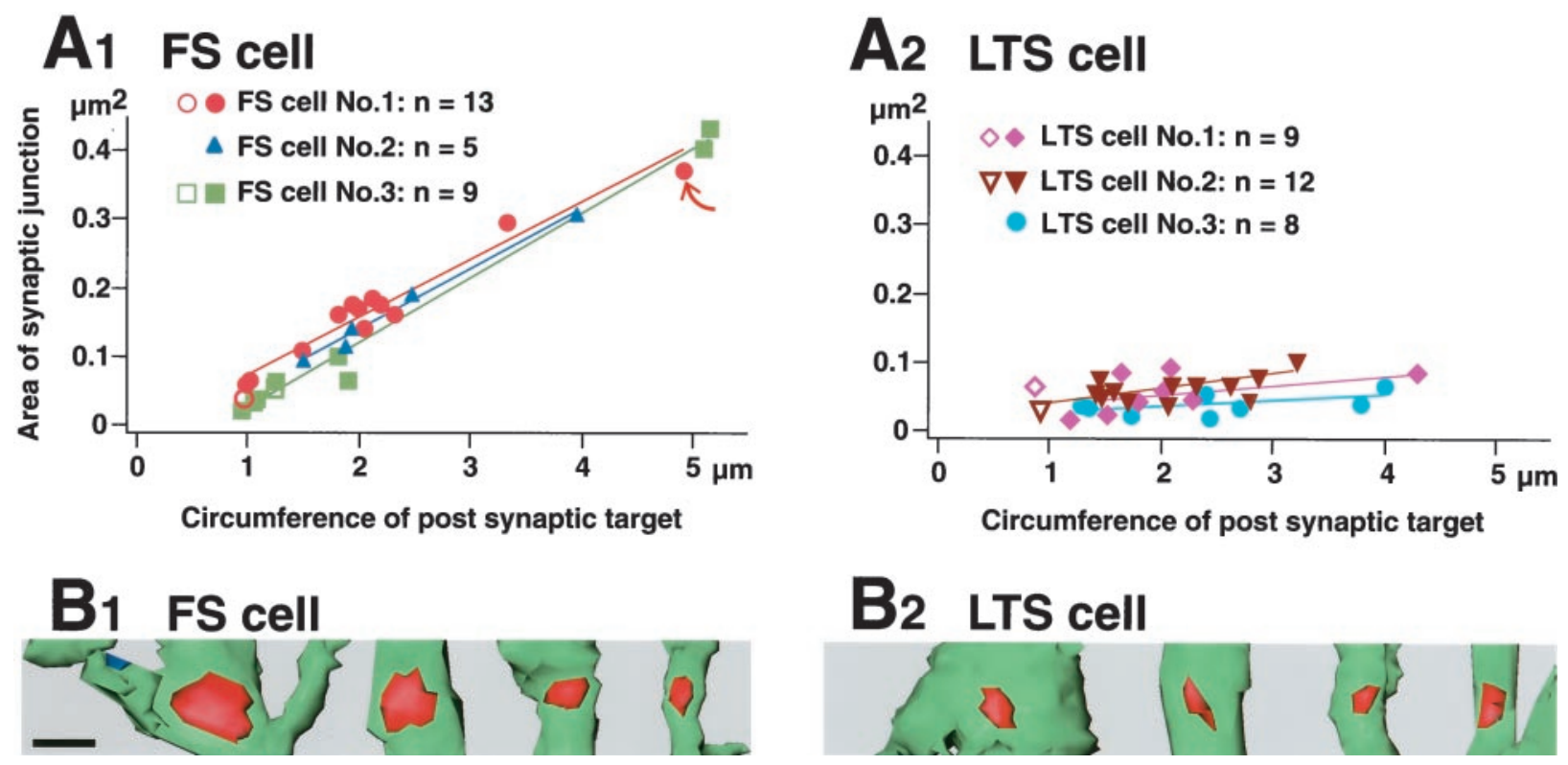

Figure 7. A, Relationship of the synaptic junction area to target structure circumference for three FS and three LTS cells. The data were obtained from the 3-D reconstructions of serial ultrathin sections. Synapses on dendritic shafts are represented by filled symbols and on spine necks by open symbols. Each solid line is a simple regression fit to a set of data. $A_{l}$, The data point indicated by the curved arrow (red) is the sum of two synapses from the same FS cell $0.8 \mu \mathrm{m}$ apart on the same target dendrite (shown in Fig. $4 B$ ). Correlation coefficients and slopes (regression coefficients) for the regression lines were: FS cell number $1(n=13$; red circles $), 0.97$ and $0.084 \mu \mathrm{m}(p<0.0001$; ANOVA test); FS cell number $2(n=5$; blue triangles $), 0.99$ and $0.087 \mu \mathrm{m}$ $(p=0.0005)$; FS cell number 3 ( $n=9$; green squares $), 0.99$ and $0.095 \mu \mathrm{m}(p<0.0001)$. $A_{2}$, Regression fits for the LTS cells showed a much less steep slope than for the FS cells and a greater spread in the data. Correlation coefficients and slopes for these cells were: LTS cell number 1 ( $n=9$; pink diamonds), 0.49 and $0.014 \mu \mathrm{m}(p=0.1818)$; LTS cell number $2(n=12$; brown inverted triangles $), 0.75$ and $0.022 \mu \mathrm{m}(p=0.0047)$; LTS cell number $3(n=8$; blue circles $), 0.58$ and $0.009 \mu \mathrm{m}(p=0.1304) . B$, 3-D reconstruction images of postsynaptic dendrites $($ green $)$ of FS $\left(B_{1}\right)$ and LTS cells $\left(\mathrm{B}_{2}\right)$. The area of the synaptic junctions (red) of the FS cells clearly increased with the size of the postsynaptic structures, whereas those of the LTS cells did not increase sharply. Scale bar, $0.5 \mu \mathrm{m}$.

dimensionally from serial ultrathin sections (Fig. 4, Table 1). Synaptic junctions made by labeled terminals were identified using the following criteria (Buhl et al., 1995): (1) tight apposition of presynaptic and postsynaptic membrane profiles with a widening of the extracellular space and a dense or intermediate plaque of intercellular materials; (2) accumulation of synaptic vesicles in the presynaptic terminal; and (3) postsynaptic density. Small synaptic junctions such as those on spine stalks and thin dendritic

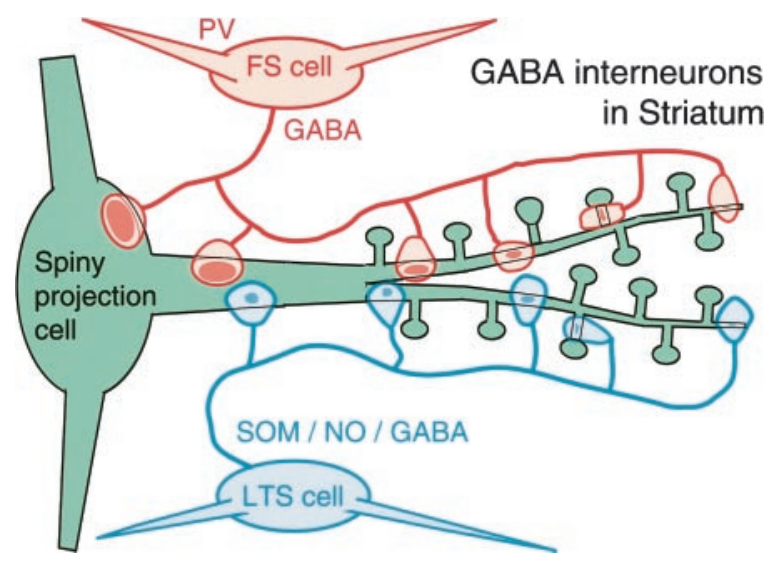

Figure 8. Schematic view of synaptic connections of GABAergic FS and LTS cells of the rat neostriatum. In FS cells, the synaptic junctional area (red regions in the terminal boutons) sharply and linearly increases with the circumference of the postsynaptic dendrite or spine. Those of the LTS cells (blue regions in the terminal boutons) demonstrate a less pronounced increment in size. $N O$, Nitric oxide; $P V$, parvalbumin; SOM, somatostatin. shafts $(0.3-0.5 \mu \mathrm{m}$ in diameter) were sometimes difficult to identify because they appeared only in a few ultrathin sections. Identification of synaptic junctions on tiny postsynaptic targets sectioned obliquely was more difficult even though the specimens were tilted to an appropriate angle for observation of synaptic clefts. Therefore, small synaptic junctions were missed more frequently than larger ones.

Reconstructed synaptic terminals showed bouton-like swellings. Most terminal boutons made one synaptic junction except three (one for an FS cell and the other two for LTS cells), making two synaptic junctions on different postsynaptic dendrites. The synaptic terminals of FS cells were of symmetrical type and made 11 contacts on somata and 28 on dendrites (Table 1; Figs. $4 A-C$, $5 A, B)$. Seventeen postsynaptic dendrites of FS cell terminals were identified as spiny from the reconstructed morphology (Fig. $4 A, C)$. Two terminals of FS cells innervated dendritic spines (Table 1). One of them made a synapse onto the stalk of a spine with an asymmetrical synapse on the head (Figs. $4 C, 5 B$ ). The other was on the head of a thin spine with an asymmetrical synapse on the opposite side of the head. Four terminals of FS cells made synapses on thick aspiny dendrites $\sim 5 \mu \mathrm{m}$ in circumference (Fig. 4B), and one terminal impinged on a thin aspiny dendrite $\sim 2 \mu \mathrm{m}$ in circumference. It was not possible to determine whether the remaining six dendrites innervated by FS cell terminals were spiny or aspiny, because the tissue structures were not well preserved. Nine somata innervated by FS cells had nuclei without folding, another had an indented nucleus. It could not be determined whether the remaining one soma had an indented nucleus or not.

The synaptic terminals of LTS cells $(n=30)$ made most 
synapses onto dendrites except for one case on the soma (Table 1; Figs. $4 D-F, 5 C, D)$. Twelve postsynaptic dendrites of LTS cell terminals were identified as spiny (Table 1, Fig. 4D-F). Two terminals made synapses onto a spine stalk with an asymmetrical synapse on the heads (Figs. $4 F, 5 D$ ). One terminal innervated a large aspiny dendrite $\sim 4 \mu \mathrm{m}$ in circumference. We could not identify whether the remaining 16 dendrites were spiny or not. One LTS terminal was found to innervate a soma without nuclear indentation (Table 1). The LTS cells had fewer synaptic contacts on somata than the FS cells.

The volume and synaptic junctional areas of the terminal boutons of FS and LTS cells were measured from the 3-D reconstructions. The synaptic junctional areas of FS cell terminals were larger on average and more variable in distribution than those of LTS cell terminals (Table 2, Fig. $6 A_{1}, B_{1}$ ). The synaptic junctional areas of FS cell terminals on somata were larger on average than those on dendrites (Table 2). Significant differences were found between the synaptic junctional areas of axodendritic and axosomatic terminals of FS cells $(p<0.005)$, axodendritic terminals of FS and LTS cells ( $p<0.0001)$, and axosomatic terminals of FS cells and axodendritic terminals of LTS cells $(p<0.0001)$ (Table 2 ). The range of bouton sizes was about the same for the FS and LTS cells, and no significant difference was found (Table 2). No correlation was found between the volume of presynaptic boutons and area of synaptic junctions in FS and LTS cells (Fig. $6 A_{2}, B_{2}$ ).

The circumference of the postsynaptic dendrites or spines was also measured. The ranges for those innervated by FS and LTS cells were similar with no significant difference (Table 2). The synaptic junctional areas of FS cells $\left(0.024-0.435 \mu \mathrm{m}^{2} ; n=28\right)$ sharply and linearly increased with the circumference of the postsynaptic dendrites or spines $(0.939-5.146 \mu \mathrm{m})\left(\right.$ Fig. $\left.7 A_{1}, B_{1}\right)$. The increase of the junctional area of LTS cells $\left(0.02-0.103 \mu \mathrm{m}^{2}\right.$; $n=29)$ with the circumference $(0.844-4.252 \mu \mathrm{m})$ was less steep (Fig. $7 A_{2}, B_{2}$ ), and the synaptic area was always $<0.103 \mu \mathrm{m}^{2}$. The correlation coefficients for total synapses of three FS cells and for those of three LTS cells were 0.98 and 0.38 , respectively. The regression line slopes (regression coefficients) were $0.09 \mu \mathrm{m}$ for total synapses of three FS cells $\left(r^{2}=0.95 ; p<0.0001\right.$; ANOVA test) and $0.01 \mu \mathrm{m}$ for those of three LTS cells $\left(r^{2}=0.14 ; p=\right.$ $0.0423)$.

These observations suggest that the dependence of synaptic junctional area on the circumference of the postsynaptic dendrite differs between neostriatal GABAergic interneuron types (Fig. 8).

\section{DISCUSSION}

The major findings of the present study can be summarized as follows (Fig. 8): (1) the axon terminals of both parvalbumin FS cells and somatostatin LTS cells are immunoreactive for GABA in immersion-fixed slices, and the GABA content at the axonal boutons of parvalbumin FS cells may be larger than that of somatostatin LTS cells; (2) FS cells make a greater proportion of synaptic contacts onto somata than LTS cells; (3) although terminal boutons of FS and LTS cells are similar in volume, their synaptic junctional areas differ in size distribution and relation to dimensions of postsynaptic dendritic shafts or spines; and (4) the junctional area of FS cells sharply and linearly increases with the circumference of the postsynaptic dendrites or spines, whereas the increment with LTS cells is less pronounced.

\section{Heterogeneity of neostriatal GABAergic interneurons}

GABA immunoreactivity was detected in the axon terminals of parvalbumin FS and somatostatin LTS cells by three different immunohistochemical stainings using neostriatal slice preparations. In perfusion-fixed tissues, most parvalbumin-immunoreactive fibers were intensely stained with GABA by double immunofluorescence, whereas only a few somatostatin-immunoreactive fibers were stained with GABA (our unpublished observations). We adopted immersion-fixed slices because GABA in the cytoplasm might be better and more rapidly fixed with immediate glutaraldehyde immersion and microwave irradiation than with glutaraldehyde perfusion. Similarly, immunoreactivity of aspartate in nerve terminals is much stronger in slices than in sections of perfusion-fixed brains (Gundersen et al., 1998). Hypoglycemia treatment before perfusion also increases aspartate immunoreactivity, suggesting that low neuronal activity in in vitro slices and hypoglycemic animals may increase the content of aspartate or GABA in axon terminals (Gundersen et al., 1998). In our immersion-fixed slices, GABA immunoreactivity was found in the terminals of FS and LTS cells, but not LA cells. Similarly, the fibers and boutons positive for parvalbumin and somatostatin were immunoreactive for GABA, but those for dopamine were not. These observations are in line with localization of GABA as a transmitter at the axon terminals.

GABA contents at the terminal boutons, from the observed density of particles, significantly differed between the two types of GABAergic interneurons. The particle density for FS cell boutons was 1.8 times larger than that of LTS cell ones identified with intracellular staining, and that for parvalbumin boutons 1.4 times larger than that for somatostatin ones identified with preembedding immunohistochemistry. These observations suggest that GABA content at the axonal boutons may vary among GABAergic interneuron types.

\section{Specialization of synaptic terminal structures for interneuron subtypes}

Because the postsynaptic targets of FS and LTS cells include spiny dendrites and somata without nuclear invagination, both may innervate spiny projection cells (Dimova et al., 1980). FS cells may also innervate aspiny interneurons because one FS terminal was observed to make a synapse onto the soma with nuclear invagination.

Although synaptic contacts onto somata were more common with FS than with LTS cells, the synaptic localization on dendrites appeared similar for the two types. Four axospinous terminals, two from FS cells and two from LTS cells, were found to make symmetrical synapses onto the stalk or head with an asymmetrical synapse on the head. This spatial arrangement of synapses on the spine would be efficient to suppress transmission of excitatory potential from the head to the shaft. In addition, many synapses of FS and LTS cells on shafts of spiny dendrites were located close to the base of the spines. Inhibitory terminals on shafts could also be associated with the regulation of excitatory inputs onto spines as well as distal parts of dendrites.

Although the terminal boutons of FS and LTS cells were similar in volume distribution, the range of the synaptic junction area of these two types was very different. The variability of junctional areas of FS cells seemed to be attributable to adaptation to the size of the postsynaptic dendrites. Although only three FS cells were analyzed, all showed the same relationship. Dependence of junctional areas on postsynaptic dimensions has also previously been observed at asymmetrical (probably excitatory) synapses onto spines. The asymmetrical synaptic specialization increases in area with the spine head volume or surface area of neostriatal spiny projection cells, cerebellar Purkinje cells, and 
hippocampal pyramidal cells (Wilson et al., 1983; Harris and Stevens, 1988, 1989).

Recently, using a combined physiological and anatomical approach, Nusser et al. (1997) demonstrated that the distribution in quantal amplitudes of IPSCs parallel that of synaptic $\mathrm{GABA}_{\mathrm{A}}$ receptor number and synapse area in cerebellar stellate neurons. Potentiation of inhibitory currents after kindling is accompanied by increase in the number of $\mathrm{GABA}_{\mathrm{A}}$ receptors and the synaptic junctional area (Nusser et al., 1998). A direct demonstration that synapse size is positively correlated with the amplitude of the postsynaptic current was recently provided by Mackenzie et al. (1999). Using calcium imaging, whole-cell recording, and electron microscopic examination of the same synapse, the amplitudes of NMDA receptor-mediated EPSCs in cultured cortical neurons was shown to be positively correlated to synaptic size. These results suggest that the synaptic junctional area could be used as a measure of relative receptor content and postsynaptic currents. GABAergic currents induced by FS cells may be larger at thicker dendrites, and a single FS cell could induce inhibitory postsynaptic currents of different amplitudes, depending on the postsynaptic dendritic size.

Voltage-gated ion channels are known to be distributed not only on somata but also on dendrites (Yuste and Tank, 1996; Magee, 1998; Magee et al., 1998; Stuart and Spruston, 1998). With a subthreshold potential, however, passive cable properties as well as voltage-dependent resting conductances are important determinants of amplitude of postsynaptic potentials. Because the circumference of the postsynaptic target is related to the input resistance (Rall, 1995) and the synaptic junctional area to the number of receptors (Nusser et al., 1997), change of junctional areas according to postsynaptic dimension may be attributable to adjustment of GABAergic currents. The dependence of synaptic areas of FS cell terminals on postsynaptic dendritic circumference may maintain the ratio of synaptic conductance and input resistance constant. Convergence of terminals from a single GABAergic interneuron on the same postsynaptic cell was not investigated in this study. However, we found two synapses of FS cell number1 $0.8 \mu \mathrm{m}$ apart on the same dendrite close to the soma $(4.91 \mu \mathrm{m}$ in circumference, $2 \mu \mathrm{m}$ distant from the soma) (Figs. $4 B, 7 A_{1}$, curved arrow). The total synaptic area of these two synapses fit on the regression line of FS cells well, suggesting that FS cells may adjust the synaptic area to postsynaptic size by making multiple synapses on the target in some cases.

The contrasting weak correlation between synaptic junctional area and postsynaptic size seen in the LTS case might have been influenced by the fact that only three cells were analyzed. However, the junctional areas were always $<0.103 \mu \mathrm{m}^{2}$, which suggests the relative constancy, so that similar postsynaptic currents may be induced in LTS cells irrespective of the synaptic location. From the axon terminals of LTS cells, several transmitters such as somatostatin, neuropeptide $\mathrm{Y}, \mathrm{NO}$, and GABA are thought to be released. Some of them may not use ionotropic receptors limited to postsynaptic junctional areas, but also G-protein-coupled receptors or extrasynaptic receptors whose effects on the target are not related to the junctional area.

Neostriatal FS cells are known to have dense innervations close to the dendritic field and express parvalbumin, whereas LTS cells have widespread innervations and express somatostatin, neuropeptide Y, and NOS. The terminals of FS cells make more synaptic contacts on somata than those of LTS cells. In addition to the differences in firing patterns, axonal arborizations, expressed molecules, and postsynaptic targets, the presently demonstrated variation in dependence of synaptic area on the target size suggests functional differentiation of GABAergic interneurons.

\section{REFERENCES}

Aoki C, Pickel V (1989) Neuropeptide Y in the cerebral cortex and the caudate-putamen nuclei: ultrastructural basis for interactions with GABAergic and non-GABAergic neurons. J Neurosci 9:4333-4354.

Augood S, Herbison A, Emson P (1995) Localization of GAT-1 GABA transporter mRNA in rat striatum: cellular coexpression with GAD67 mRNA, GAD67 immunoreactivity, and parvalbumin mRNA. J Neurosci 15:885-874.

Bennett BD, Bolam JP (1994) Synaptic input and output of parvalbumin-immunoreactive neurons in the neostriatum of the rat. Neuroscience 62:707-719.

Bolam JP, Bennet BD (1995) Microcircuitry of the neostriatum. In: Molecular and cellular mechanism of neostriatal function (Arino M, Surmeier D, eds), pp 1-19. Austin: R.G. Landes.

Buhl E, Halasy K, Somogyi P (1994) Diverse sources of hippocampal unitary inhibitory postsynaptic potentials and the number of synaptic release sites. Nature 368:823-828.

Buhl E, Cobb S, Halasy K, Somogyi P (1995) Properties of unitary IPSPs evoked by anatomically identified basket cells in the rat hippocampus. Eur J Neurosci 7:1989-2004.

Catania M, Tölle T, Monyer H (1995) Differential expression of AMPA receptor subunits in NOS-positive neurons of cortex, striatum, and hippocampus. J Neurosci 15:7046-7061.

Chesselet M, Robbins E (1989) Characterization of striatal neurons expressing high levels of glutamic acid decarboxylase messenger RNA. Brain Res 492:237-244.

Cowan R, Wilson CJ, Emson P, Heizmann C (1990) Parvalbumincontaining GABAergic interneurons in the rat neostriatum. J Comp Neurol 302:197-205.

Deuchars J, West DC, Thomson AM (1994) Relationships between morphology and physiology of pyramid-pyramid single axon connections in rat neocortex in vitro. J Physiol (Lond) 478:423-435.

Dimova R, Vuillet J, Seite R (1980) Study of the rat neostriatum using a combined Golgi-electron microscope technique and serial sections. Neuroscience 5:1581-1596.

Freund TF, Buszáki G (1996) Interneurons of the hippocampus. Hippocampus 6:347-470.

Gundersen V, Chaudhry F, Bjaalie J, Fonnum F, Ottersen O, StormMathisen J (1998) Synaptic vesicular localization and exocytosis of L-aspartate in excitatory nerve terminals: a quantitative immunogold analysis in rat hippocampus. J Neurosci 18:6059-6070.

Harris K, Stevens J (1988) Dendritic spines of rat cerebellar Purkinje cells: serial electron microscopy with reference to their biophysical characteristics. J Neurosci 8:4455-4469.

Harris K, Stevens J (1989) Dendritic spines of CA1 pyramidal cells in the rat hippocampus: serial electron microscopy with reference to their biophysical characteristics. J Neurosci 9:2982-2997.

Jefferys JGR, Whittington MA, Traub RD (1996) Neuronal networks for induced " $40 \mathrm{~Hz}$ " rhythms. Trends Neurosci 19:202-208.

Kawaguchi Y (1993) Physiological, morphological and histochemical characterization of three classes of interneurons in rat neostriatum. J Neurosci 13:4908-4923.

Kawaguchi Y (1997) Neostriatal cell subtypes and their functional roles. Neurosci Res 27:1-8.

Kawaguchi Y, Kubota Y (1997) GABAergic cell subtypes and their synaptic connections in rat frontal cortex. Cereb Cortex 7:476-486.

Kawaguchi Y, Kubota Y (1998) Neurochemical features and synaptic connections of large physiologically-identified GABAergic cells in the rat frontal cortex. Neuroscience 85:677-701.

Kawaguchi Y, Wilson C, Augood S, Emson P (1995) Striatal interneurons: chemical, physiological and morphological characterization. Trends Neurosci 18:527-535.

Kita H, Kosaka T, Heizmann CW (1990) Parvalbumin-immunoreactive neurons in the rat neostriatum: a light and electron microscopic study. Brain Res 536:1-15.

Koós T, Tepper JM (1999) Inhibitory control of neostriatal projection neurons by GABAergic interneurons. Nature Neurosci 2:467-472.

Kubota Y, Mikawa S, Kawaguchi Y (1993) Neostriatal GABAergic interneurons contain NOS, calretinin or parvalbumin. NeuroReport $5: 205-208$

Mackenzie PJ, Kenner GS, Prange O, Shayan H, Umemiya M, Murphy 
TH (1999) Ultrastructural correlates of quantal synaptic function at single CNS synapses. J Neurosci 19:RC13 (1-7).

Magee JC (1998) Dendritic hyperpolarization-activated currents modify the integrative properties of hippocampal CA1 pyramidal neurons. J Neurosci 18:7613-7624.

Magee J, Hoffman D, Colbert C, Johnston D (1998) Electrical and calcium signaling in dendrites of hippocampal pyramidal neurons. Annu Rev Physiol 60:327-346.

Nusser Z, Cull Candy S, Farrant M (1997) Differences in synaptic $\mathrm{GABA}_{\mathrm{A}}$ receptor number underlie variation in GABA mini amplitude. Neuron 19:697-709.

Nusser Z, Hájos N, Somogyi P, Mody I (1998) Increased number of synaptic $\mathrm{GABA}_{\mathrm{A}}$ receptors underlies potentiation at hippocampal inhibitory synapses. Nature 395:172-177.

Phend K, Weinberg R, Rustioni A (1992) Techniques to optimize postembedding single and double staining for amino acid neurotransmitters. J Histochem Cytochem 40:1011-1020.

Rall W (1995) The theoretical foundation of dendritic function (Segev I, Rinzel J, Shepherd GM, eds). Cambridge, MA: MIT.

Sillito AM (1992) GABA-mediated inhibitory processes in the function of the geniculo-striate system. In: Progress in brain research, Vol 90, GABA in the retina and central visual system (Mize RR, Marc RE, Sillito AM, eds), pp 349-384. Amsterdam: Elsevier.

Somogyi P, Tamás R, Lujan R, Buhl E (1998) Salient features of synaptic organisation in the cerebral cortex. Brain Res Rev 26:113-135.

Stuart G, Spruston N (1998) Determinants of voltage attenuation in neocortical pyramidal neuron dendrites. J Neurosci 18:13501-3510.

Thomson AM, Deuchars J (1997) Synaptic interactions in neocortical local circuits: dual intracellular recordings in vitro. Cereb Cortex 7:510-522.

Vuillet J, Kerkerian-Le Goff L, Kachidian P, Dusticier G, Bosler O, Nieoullon A (1990) Striatal NPY-containing neurons receive GABAergic afferents and may also contain GABA: an electron microscopic study in the rat. Eur J Neurosci 2:672-681.

Wilson CJ, Groves P, Kitai ST, Linder J (1983) Three-dimensional structure of dendritic spines in the rat neostriatum. J Neurosci 3:383-388.

Yuste R, Tank DW (1996) Dendritic integration in mammalian neurons, a century after Cajal. Neuron 16:701-716. 